\title{
ANALYSIS OF THE CALCULATION OF PRODUCTION COSTS AND SELLING PRICES IN UD. BINA USAHA BAGUSARI
}

\author{
Juniar Sugiarti, Sochib, Yanna Eka Pratiwi \\ Departement of Accountinng, STIE Widya Gama Lumajang, Indonesia \\ Email: yannapratiwiy@gmail.com
}

\section{A R T ICLE IN F O}

Date of entry:

12 January 2020

Revision Date:

14 February 2020

Date Received:

3 June 2020

\begin{abstract}
A B S T R A C T
Business (company) is an organization that provides a variety of goods or services for sale with the aim of obtaining profits. Accounting calculations on companies are needed at the production price and selling price at a company. In this case then direct this research in the calculation of production prices and selling prices. The data needed in this study can be obtained through documentation and field research. The data obtained in this analysis uses the Descriptive Quantitative method, based on the analysis shows that the calculation of production costs and selling prices using the calculation method carried out by the UD with the calculation of production costs using the variable costing method is lower than the calculations made by the company. Because the variable costing method calculates the variable costs associated with the production process and selling prices while the calculation method applied by the company lists all costs including variable overhead costs and fixed overhead costs. So that there is a difference in production costs and selling prices according to company methods and variable costing methods.
\end{abstract}

Keywords: Calculation Of Production Costs, Selling Prices, Calculation Methods.

Cite this as: Sugiarti, Juniar., Sochib., Juliasari, Deni. (2020). ANALYSIS OF THE CALCULATION OF PRODUCTION COSTS AND SELLING PRICES IN UD. BINA USAHA BAGUSARI. Assets : Jurnal Ilmiah Ilmu Akuntansi, Keuangan dan Pajak, 4(2), 57-65

\section{INTRODUCTION}

Every company must be able to compete in order to survive, so the company must have long-term competitiveness for the products it produces. Business (company) is an organization that provides various goods or services for sale with the aim of making a profit. The prospect of making a profit is the difference between revenue and business costs, which is an incentive for people to start and grow their businesses.

The more intense competition in the business world, the company must increase efficiency in the calculation of production costs and selling prices because it is the basis for companies to determine production costs and the selling price of their products. So that if the calculation of production costs and selling prices is carried out correctly, the right production costs and selling prices will be obtained. One of the ways that can be done to increase cost efficiency is by controlling production costs and the selling price of the company. 
This study replicates the research conducted by Salis Istimaroh in 2016 regarding the Calculation of Production Costs and Selling Prices Using Variable Costing at WIN BAKERY MSMEs in Jepara. The difference between previous research and current research lies in the object of research, namely the previous research of UMKM while the current research is UD. The equation lies in the objective, namely to find out that the variable costing method plays a role in the calculation of production costs.

\section{METHODS}

This type of research is conducting research related to issues concerning production costs and sales costs which will be discussed in this study, so the type of research that will be used is descriptive quantitative research. Nana Sudjana and Ibrahim (2001) state that the definition of descriptive quantitative research is based on research. Meanwhile, according to Suriasumantri (2005) quantitative research is conducted with a scientific study of thought. This study uses a logicoverification process in the research steps carried out.

From the explanations and definitions above, it can be concluded that descriptive quantitative research. The number of objects in quantitative research is generally limited. In research, researchers in events / conditions. For that the results of this study require a depth of analysis from the researcher. In addition, the results of this study are subjective so that they cannot be generalized. In general, quantitative research is carried out by means of documentation and observation methods. Through this method, researchers will analyze the data obtained from the field.

The method used to analyze the data is descriptive quantitative analysis, the steps taken in analyzing the data are:

1. Measuring production costs including measurement of raw material costs and direct labor costs

2. Calculating the cost of production

3. Analyze the calculation of production costs.

4. Perform analysis of sales cost calculations

5. Analyze production costs against sales costs

Data analysis was carried out by quantitative analysis. Quantitative analysis is done by calculating the cost of goods manufactured using the variable costing method. The production cost elements used in the calculation of the variable costing method are as follows:

1. Raw material costs

2. Direct labor costs

3. Variable factory overhead costs

4. Fixed factory overhead costs

5. Cost of production

\section{RESULTS AND DISCUSSION}

UD Bina Usah is one of UD which produces processed soybeans into tempe, where UD is a good business and is busy with customers, both from the village area of Bagusari and in the market and its surroundings. UD Bina Usaha sells tempe whose consumers come from various backgrounds, both young and adult, especially housewives in Lumajang Regency. UD Bina Usaha was founded about 5 years ago with its address at Jalan Mahakam, Jogotrunan Village, Lumajang District, Lumajang Regency by Mr. Fatchur Rozi as the owner of UD Bina Usaha.

The owner as well as UD Bina Usaha, Mr. Rozi, has the authority and decision makers in his business activities and is overall responsible for running his business. The Finance Section in UD 
Bina Usaha named Mrs. Sunarsih is in charge of recording and calculating income and expenses. Production process activities are divided into four parts consisting of:

a. Cleaning Process Section

First, choose soybeans that are not rotten and not dirty. Then the soybeans are cleaned using clean water. In this case the water used is well water. Then the cleaned soybeans are soaked in a bucket / barrel for one night so that the skins come off easily.

b. The stripping process section

Soybeans that have been soaked for one night are peeled by trampling them or using a soy peeler

c. Steaming Process Section

After peeling and washing, the soybeans are steamed in a pan for 1 hour. Then remove and chill in a large pan

d. Fermentation Process

This process is carried out after the soybeans have cooled. Tempeh yeast is put into the soybean bath then stirred until evenly distributed

e. Storage process

Stack the molds and cover them with burlap sacks to keep them warm. After 1 night the mushrooms start to grow and come out hot

In this case, the UD business. Bina Usaha has a very simple organizational structure, where the owner of the company acts as the leader of the company and is directly in charge of boiling, milling, and part of marketing and sales.

\section{Data Collection Results}

Equipment Used in Tempe Production

There are several things that must be prepared before producing tempe, as for the equipment and raw materials that need to be prepared. The equipment used in producing tempe each has a different function. The equipment used in the tempe production process can be seen at

Table 1. Tempe Production Equipment UD. Bina Usaha

\begin{tabular}{clccc}
\hline No & Description & Volume (Unit) & Purchase Price (idr/Unit) & Total Cost \\
\hline 1 & Water Tub (3M3) & 2 & 400.000 & 800.000 \\
2 & Plastic Tub & 6 & 50.000 & 300.000 \\
3 & Print & 2 & 150.000 & 300.000 \\
4 & Cormorant & 5 & 1.000 .000 & 5.000 .000 \\
5 & Jerry Can (20Lt) & 2 & 40.000 & 80.000 \\
6 & Plastic Basket & 6 & 20.000 & 120.000 \\
7 & Fan & 3 & 500.000 & 1.500 .000 \\
8 & Diesel engine & 1 & 2.500 .000 & 2.500 .000 \\
9 & Milling Machine & 1 & 2.500 .000 & 2.500 .000 \\
10 & Water pump & 1 & 780.000 & 780.000 \\
11 & Filter & 2 & 200.000 & 400.000
\end{tabular}


Source: processed from primary data

It is known that the number of tempe products produced per day is 2,900 pieces, so the tempe production that occurs during December 2019 is 31 days x 2,900 $=89,900$ pieces of tempe.

Table 2. Calculation of the Cost of Production of Tempe in December 2019.

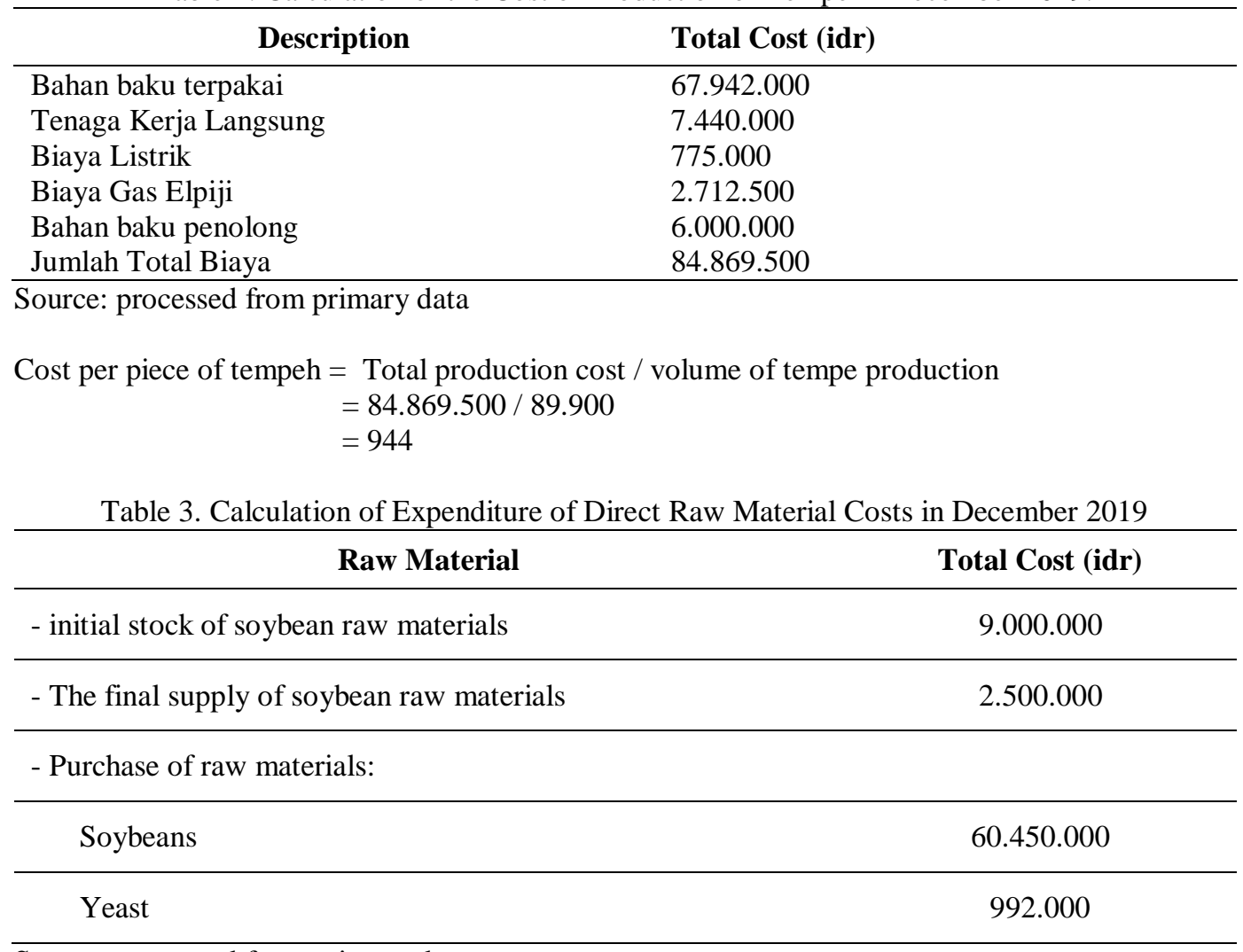

Source: processed from primary data

Table 4. Total expenditure on direct raw material production in December 2019

\section{Raw Material}

initial supplies of soybean raw materials

Purchase of raw materials

The final supply of soybean raw materials

Total raw material costs

\section{Total Cost (idr)}

9.000 .000

61.442 .000

$(2.500 .000)$

67.942.000

Source: processed from primary data 


\begin{tabular}{lcccc}
\hline \multicolumn{1}{c}{ Description } & Volume & Salary.day & $\begin{array}{c}\text { Total } \\
\text { Number } \\
\text { of } \\
\text { Working } \\
\text { Days }\end{array}$ & Total Cost \\
Boiling \& Milling & 3 & 40.000 & 31 & 3.720 .000 \\
Fermentation \& Packaging & 3 & 40.000 & 31 & 3.720 .000 \\
$\begin{array}{l}\text { Total Salary for December 2019 } \\
\text { Total overtime pay during December }\end{array}$ & & & & 7.440 .000 \\
2019 & & & & 0 \\
$\begin{array}{l}\text { Total direct labor costs for December } \\
2019\end{array}$ & & & $\mathbf{7 . 4 4 0 . 0 0 0}$ \\
\hline Source: processed from primary data & & & &
\end{tabular}

Table 6. Factory Overhead Cost of UD. Business Development in December 2019

\begin{tabular}{l|c}
\multicolumn{1}{c|}{ Factory Overhead Cost Information } & Total Cost (idr) \\
\hline Cost of Auxiliary Materials & 6.000 .000 \\
Electricity cost & 775.000 \\
The cost of eating and drinking & 2.000 .000 \\
Total Factory Overhead Costs for December 2019 & $\mathbf{8 . 7 7 5 . 0 0 0}$ \\
\hline
\end{tabular}

Source: processed from primary data

Table 7. Overhead Costs Using The Variable Costing Method

\begin{tabular}{l|c}
\hline \multicolumn{1}{c|}{ Variable Overhead Cost Information } & Total Cost (idr) \\
\hline Cost of Auxiliary Materials & 6.000 .000 \\
Electricity cost & 775.000 \\
Total Factory Overhead Costs for December 2019 & 6.775 .000 \\
\hline
\end{tabular}

Source: processed from primary data

Table 8. Fixed overhead costs

\begin{tabular}{|c|c|}
\hline Fixed Overhead Cost Information & Total Cost (idr) \\
\hline The cost of eating and drinking & 2.000 .000 \\
\hline Total Fixed Factory Overhead Costs in December 2019 & 2.000 .000 \\
\hline
\end{tabular}

Source: processed from primary data

Table 9. Calculation of the Cost of Production of Tempe using the Variable Costing Method

\begin{tabular}{lc}
\hline \multicolumn{1}{c}{ Description } & Total Cost (idr) \\
\hline Direct Raw Material Costs & 67.942 .000 \\
\hline Direct labor costs & 7.440 .000 \\
\hline Factory Overhead Cost (variable) & 6.775 .000 \\
\hline
\end{tabular}


78.869.500

Divided the amount of tempe production in December 2019

89.900

Cost of Production Per Cut Tempe

877,30

Source: processed from primary data

Table 10. Comparison between the Calculation of Cost of Production

\begin{tabular}{|c|c|c|c|}
\hline Description & $\begin{array}{l}\text { Calculation } \\
\text { production costs }\end{array}$ & $\begin{array}{l}\text { Variabel } \\
\text { Coasting }\end{array}$ & Difference \\
\hline & A (idr) & B (idr) & $\mathrm{C}=\mathrm{B}-\mathrm{A}(\mathrm{idr})$ \\
\hline Tempe Production Cost & 944 & 877,30 & 67 \\
\hline \multicolumn{4}{|c|}{ The number of tempe production in December 2019 was 89,900 units } \\
\hline $\begin{array}{l}\text { The total difference in the cost of } \\
\text { production is the second } \\
\text { calculation }\end{array}$ & & $\begin{array}{l}(\mathrm{C} \\
\mathbf{8 9 . 9 0 0})\end{array}$ & 6.023 .300 \\
\hline
\end{tabular}

Source: processed from primary data

It can be seen that the cost of production of tempe using the variable costing method in December 2019 is Rp. 877.30. Comparison of the Calculation Results of Cost of Production by the Company and the Variable Costing Method can be compared the two calculations of the cost of production of tempe UD. Business Development in December 2019.

Table 11. Calculation of the Selling Price of UD. Bina Usaha

\begin{tabular}{|c|c|}
\hline Description & Cost (idr) \\
\hline Raw Material Costs & 67.942 .000 \\
\hline Direct labor costs & 7.440 .000 \\
\hline Fixed Overhead Costs & 2.000 .000 \\
\hline Variable Overhead Costs & 6.775 .000 \\
\hline Total Production Costs & 84.157 .000 \\
\hline Expected profit $20 \%$ & 16.831 .400 \\
\hline Selling price & 100.998 .400 \\
\hline Total Production & 89.900 \\
\hline Selling price per piece & $1.123,4$ \\
\hline
\end{tabular}

Source: processed from primary data

Table 12. The calculation of the selling price

\begin{tabular}{|c|c|}
\hline Description & Cost (idr) \\
\hline Raw Material Costs & 67.942 .000 \\
\hline Direct labor costs & 7.440 .000 \\
\hline Variable Overhead Costs & 6.775 .000 \\
\hline Total Production Costs & 82.157 .000 \\
\hline
\end{tabular}




\begin{tabular}{ll}
\hline Expected profit 20\% & 16.431 .000 \\
\hline Selling price & 98.558 .400 \\
\hline Total Production & 89.900 \\
\hline Selling price per piece & $1.096,65$ \\
\hline
\end{tabular}

Source: processed from primary data

Table 13. Comparison of Selling Prices

\begin{tabular}{|c|c|c|c|}
\hline \multirow{2}{*}{ Description } & \multicolumn{2}{|c|}{ Selling price } & \multirow{2}{*}{$\begin{array}{l}\text { Selisih Harga } \\
\text { Jual (Rp) }\end{array}$} \\
\hline & Company Method (idr) & Variable Costing (idr) & \\
\hline $\begin{array}{l}\text { UD. Bina } \\
\text { Usaha }\end{array}$ & $1.123,40$ & $1.096,65$ & 26,70 \\
\hline
\end{tabular}

Source: processed from primary data

Calculation of the Cost of Production of Tempe UD. Business Development

Calculation of Tempe Production Cost by the Company. As for the calculation of the cost of production of tempe carried out by the company, it can be seen that the cost of production per piece of tempe in December 2019 was Rp. 944. Cost of production per piece of tempe is obtained from the sum of all costs associated with production then divided by the amount of tempe production.

Calculation of the Cost of Production of Tempe using the Variable Costing Method

The thing that needs to be considered in calculating the cost of production of tempe with the variable costing method is to specify the variable costs included in the production costs, such as direct raw material costs, direct labor costs, and variable factory overhead costs that are fixed or variable.

\section{Raw Material Costs}

Supervision of raw material for soybeans is carried out once a week as much as $1,820 \mathrm{~kg}$, without any discount on raw material prices and raw material transportation costs. The initial inventory of soybean raw materials for December 2019 was $1,820 \mathrm{~kg}$ and the final raw material inventory in November 2019 was $1,200 \mathrm{~kg}$, with a price per kilogram of Rp. 7,500, -. For the raw material for yeast that is needed each month is $248 \mathrm{~kg}$ at a price of Rp. 32,000 per kilogram. The purchase of soybeans used in the production process in December 2019 is Rp. 60,450,000 and a fee for using yeast during December 2019 of Rp. 992,000. Calculation of the cost of raw materials required in the tempe production process. Based on existing data, it can be seen that the total cost of raw materials used in December 2019 was Rp. 67,942,000 to produce 89,900 pieces of tempe.

Calculation of direct labor costs required by UD tempe business. Business Development in December 2019 can be seen that the total cost of direct labor in December 2019 is IDR 7,440,000. Factory Overhead Costs

Factory overhead costs are all costs to produce a product other than direct raw materials and direct labor, namely indirect raw materials, indirect labor, and all other indirect costs (Mulyadi 2015: $16)$.

Factory Overhead Costs consist of costs for auxiliary materials, electricity costs, maintenance and maintenance costs for machines and equipment, depreciation costs for buildings and machinery and equipment. Until we find the total cost of Fixed and Variable Factory Overhead of Rp. $2,000,000$ and Rp. 6,775,000

The selling price calculation is adding the production cost with the expected profit contribution. It is known that the selling price calculation using the company method is IDR 1,123.40. This price 
is obtained from the cost of production plus the percentage of profit expected by the company then divided by the amount of production. The company wants a profit of $20 \%$ on this product.

Calculation of Selling Price Determination using Variable Costing Method

The production cost calculation is used to determine the selling price. The goal is that companies do not sell prices below production costs. The details of determining the selling price using the variable costing method can be seen that the calculation of the selling price using the variable costing method is Rp. 1,096.65. From the comparison of the selling price of the two methods, it can be seen that the selling price using the variable costing method is lower than the selling price using the company method. The following is a comparison of the selling price using the variable costing method and the company method.

It can be seen that the calculation of the cost of production carried out by the company and the variable costing method have differences. In calculating the cost of production using the variable costing method, the resulting cost of goods manufactured is lower than the calculation of the cost of production carried out by the company. This is because the use of the variable costing method clearly details all production costs, be it raw material costs, direct labor costs, and factory overhead costs. While there is a calculation of the cost of production carried out by the company, the costs included in production costs are variable costs and fixed costs including raw materials, direct labor costs, and some variable factory overhead costs, fixed overhead costs such as electricity costs and LPG gas costs.

This causes the calculation of the cost of production by the company to be greater than the calculation of the cost of production using the variable costing method, because calculating the fixed overhead costs should be more for personal needs not for company needs.

If the tempe business of UD. Bina Usaha uses the variable costing method in calculating the cost of production or production costs of their business tempe, so the company must identify all costs used in the production process, separate production costs from non-production costs, distinguish between fixed costs and variable costs, and calculate costs. production in addition to raw material costs, direct labor costs, and variable factory overhead costs and fixed overhead costs in detail and detail.

Based on the data above, it can be seen that the selling price using the variable costing method is lower than using the company method. With the difference between the two methods is Rp. 26.70. This is because using variable costing calculates variable costs related to the production process, be it raw material costs, direct labor costs, and variable factory overhead costs. Meanwhile, the calculation of the selling price using the UD method. Business Development results are higher because the company calculates variable factory overhead costs and fixed overhead costs in detail into the selling price. The company calculates in detail the cost of raw materials, direct labor costs, and variable and fixed factory overhead costs. So that the calculation of production costs and selling prices using the company method is higher than the calculation of production costs and selling prices using the variable costing method in the short term.

\section{CONCLUSION}

Based on the discussion in the previous chapter, there is a conclusion as follows :

- UD. Bina Usaha has calculated production costs and selling prices using a simple method. The production cost component calculated by the company only includes direct raw material costs, direct work costs, and some variable factory overhead costs and fixed costs.

- The results of the calculation of the production cost determined by the company are Rp. $84,302,000.00$ with an expected percentage of $20 \%$, namely obtaining a selling price of Rp. $1,125.28$ per piece. Meanwhile, the calculation of production costs using the variable costing method yields Rp. $82,157,000.00$ with an expected percentage of $20 \%$, obtaining a selling price of Rp. 1,096.65 per piece. 
- The results of the calculation of production costs using variable costing are lower than the calculations made by the company. This is because the variable costing method calculates variable costs related to the production process which includes raw material costs, direct labor costs, and variable factory overhead costs including electricity costs and water costs. The difference in production costs according to the company method and the variable costing method is IDR 9,787,500.00 with a selling price difference of IDR 28.63.

\section{REFERENCE}

Arikunto, S. (1998). Prosedur Penelitian Suatu Pendekatan Praktek . Jakarta : Rineka Cipta Bitsstream. 2011. Perhitungan Biaya Produksi dalam Menentukan Harga Jual pada PT Persada, Universitas Sumatera Utara.

Bustami, Bastian dan Nurlela. 2006. Akuntansi Biaya Teori dan Aplikasi. GRAHA ILMU. Yogyakarta.

Darmawan, D. (2014). Metode Penelitian Kuantitatif. Bandung: Remaja Rosdakarya.

Djumali, dkk. 2014. Perhitungan Harga Pokok Produksi menggunakan Metode Variable Costing dalam Proses Penentuan Harga Jual pada PT. Sari Malalugis Bitung. Jurnal Berkala Iimiah Efisiensi. Vol. 14 No.2.

Dunia, Firdaus A. danWasilah. 2009. Akuntansi Biaya. Edisi 2. Salemba Empat. Jakarta Griffin, R.W., dan Ronald J. Ebert. 2007. Bisnis. Edisi Kedelapan.

Dr. Darsono P. SE., SF., MA., MM., dan Dewi Utari SE., M.Ak. 2016. Manajemen SDM Abad 21.Penerbit Mitra Wacana Media. Jakarta.

Erlangga. Jakarta. Hansen dan Mowen. 2009. Akuntansi Manajerial. Salemba Empat. Jakarta.

Gabriela Charteris. 2019. Analisis Perhitungan Harga Pokok Produksi Dengan Menggunakan Metode Variable Costing Sebagai Dasar Untuk Menentukan Harga Jual Batik Pada UD Rangsang Batik Yosowilangun. STIE Widya Gama Lumajang.

Gitosudarmo, Indriyo dan Nyoman Sudita. 2007. Perilaku Keorganisasian. Edisi Pertama. Cetakan Kedua. Penerbit BPFE. Yogyakarta.

Half, R. (2019, $10 \quad$ 26). Retrieved Februari 18, 2020, from https://www.gurupendidikan.co.id/pengertian-akuntansi/

Handoko, T. Hani, 2008. Manajemen Sumberdaya Manusia. Penerbit BPFE. Yogyakarta.

Hasibuan, Malayu S.P, 2006. Manajemen Sumber Daya Manusia. Cetakan Kelima. Edisi Revisi. Bumi Aksara . Jakarta

Hasan, Iqbal 2009 . Analisis Data PenelitianStatistik.BumiAksara : Jakarta

Kuncoro, Mudrajad. 2013. Metode Riset Untuk Bisnis dan Ekonomi. Erlangga, Jakarta. Pengertian Laba Akuntansi. Jurnal Bang Vanda. 2012.07

Mamad Safii. 2018. Perhitungan Harga Pokok Produksi dalam Menentukan Harga Jual Produk Pada PB Dunia Usaha. STIE Widya Gama Lumajang.

Metode Variable Costing Sebagai Dasar Untuk Menentukan Harga Jual Batik Pada UD Rangsang Batik Yosowilangun. STIE Widya Gama Lumajang.

Nilti Nikmah. 2019. Analisis Penentuan Biaya Overhead Pabrik Untuk Menentukan Harga Pokok Produk Pada UD Mandiri Agung Lumajang. STIE Widya Gama Lumajang.

Salis Istimaroh. 2016. Perhitungan Biaya Produksi dan Harga Jual Menggunakan Variable Costing pada UMKM WIN BAKERY di JEPARA. Universitas Dian Nuswantoro

Silaen, Sofar. (2014). Metodologi Penelitian Sosial Untuk Penulisan Skripsi. Bogor: InMedia.

Siregar, Sofiyan. 2013. Metode Penelitian Kuantitatif: dilengkapi dengan Perbandingan Perhitungan Manual dan SPSS. Penerbit Prenada Media Group. Jakarta

Sugiyono, 2009. Metode Penelitian Kuantitatif, Kualitatif dan R\&D. Alfabeta:Bandung.

Umar, H. (2011). Metode Penelitian Untuk Skripsi dan Tesis Bisnis. Jakarta: Rajagrafindo. 